\title{
The Reflections of Pre-service Music Teachers' Creative Thinking Skills on their Instrumental Improvisation Ability*
}

\section{Research Article}

\section{Aslı KAYA ${ }^{1}$, Sermin BILEN ${ }^{2}$}

${ }^{1}$ Mugla Sitki Kocman University, Faculty of Education, Department of Music Education, Muğla, Turkey, ORCID: 0000-0001-9453-5556

${ }^{2}$ Dokuz Eylul University, Faculty of Education, Department of Music Education, İmir, Turkey, ORCID: 0000-0002-9287-4615

To cite this article: Kaya, A., \& Bilen, S. (2021). The reflections of pre-service music teachers' creative thinking skills on their instrumental improvisation ability, International Online Journal of Educational Sciences, 13(4), 11791197.

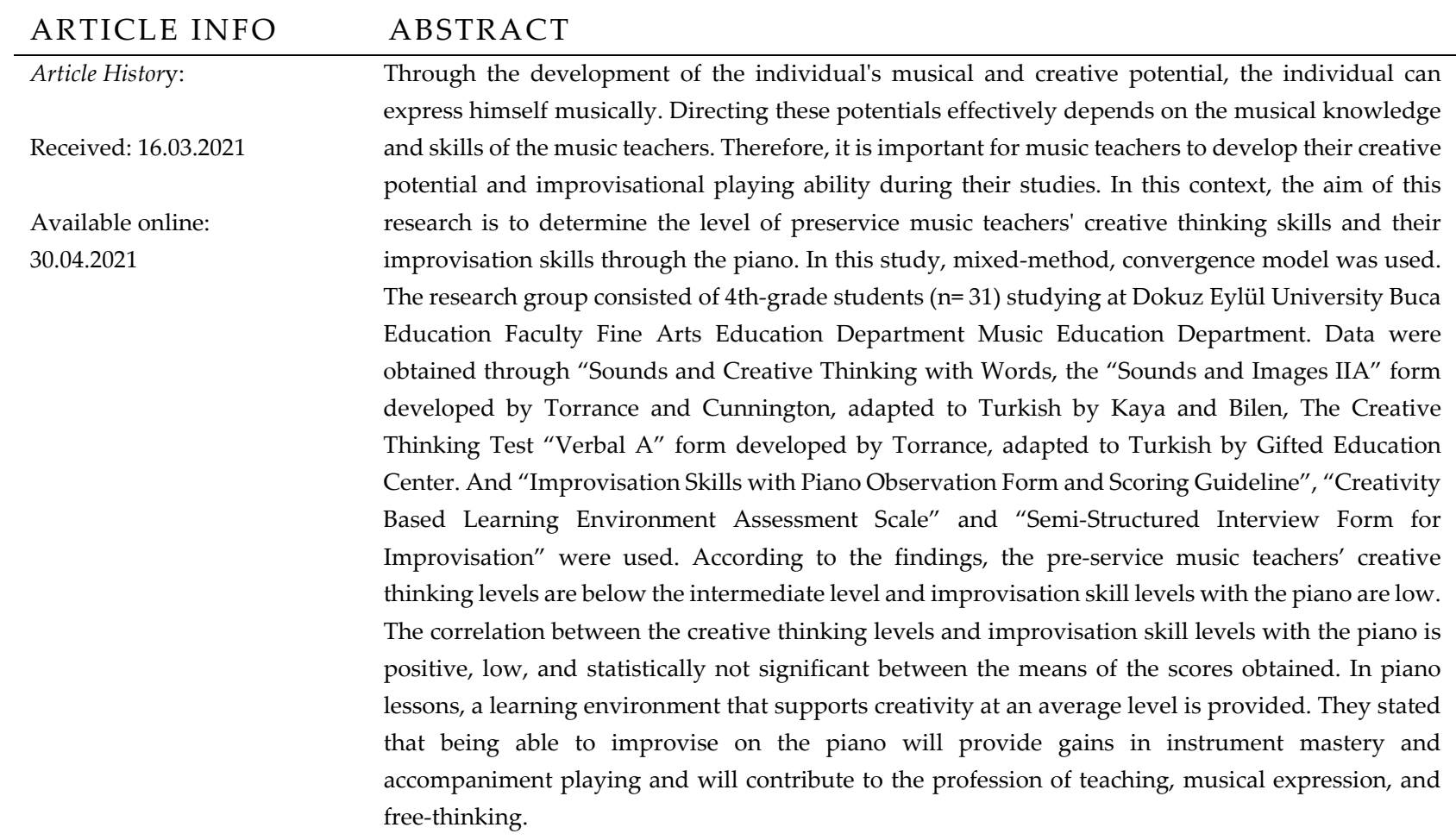




\section{Introduction}

Today's expectations and the necessity of individuals to have qualities that enable them to have a critical approach, come up with alternatives in the face of problems and solve them, gradually increase. Meeting these expectations, on the other hand, is associated with the improvement of critical thinking skills.

In creativity, there is a matter of considering synonyms and antonyms along with each other, organizing the data wisely, solving the problem with flexible approaches, and presenting a decent product. Creativity is generally defined as "being sensitive to problems, disorders, lack of knowledge, missing factors, and disharmony, acknowledging the difficulty, seeking for a solution, making predictions or developing hypothesizes regarding deficiencies, changing or retesting these hypothesizes and presenting the result afterwards." (Torrance, 1974, as cited in Sungur, 1992, p.20).

According to Wegerif (2007, pp. 152-156), creative thinking is a free, dynamic, and productive process. Creative thinking skills enable children to create new thoughts and present ideas, come up with a hypothesis, use their imagination, and seek alternative, innovative results. According to Landau (1969), creativity is the ability to correlate new connections that have not been made before, and by this way, to present new experiences, new and unique ideas, and products in a new cast of mind (As cited in San, 1993, p. 72).

Although the ability to produce creative products is related to many fields, it can be said that art and music are the most favorable fields for it. Creativity in art, according to Conrard, is the creative search, research, and finding process, which includes concepts, emotions, and imaginations, creating a beginning for the birth process of an effective metaphor associated with sensations and emotions emerged from senses (As cited in San, 1977: 15). Without creative elements, imagination is no different from purposeless fantasy or even delusion. Each artwork contains one or more images (San, 2004, p. 27). The artistic creativity process deals with thinking with images. As a natural requirement of human perceptions, these images occur in the artist's mind through the external world (San, 1985, p. 18). Musical creativity, on the other hand, is a skill where individuals can express their personal relationships through the sound field and use their mind, body, and spiritual skills. It takes part in every activity related to musical performance, such as listening, playing, improvisation, directing, arranging, and composing (Padula, 2009, p. 609).

Wigram (2005, p. 25) states that the freer and more flexible way of producing music than any style and playing through hearing is improvisation. Wigram also states that music improvisation occurs by developing and applying the harmonic, melodic, and rhythmic structure that constitutes the music within the framework of the beginning and ending, and the performance of different combinations of sounds created by adhering to these structures in a simple or complex degree, and Volz (2005), on the other hand, express that giving students time to explore their own sounds or the sounds of their instruments, regardless of age or skill level, is the first step to help them become successful on improvisation. Therefore, individuals can easily express themselves creatively through improvisation, which is one of the most natural ways of making music and is open to improvement.

Gordon states that the creative process can be analyzed, and regardless of the subject of the research (technical, scientific, aesthetic), the creative process always activates the same mechanisms, and the creation processes show similarity in individuals and groups (As cited in Rouquette, 1992, p. 68). Guilford can note that creativity and qualities specific to creative individuals should be examined, that creative abilities determine whether an individual can produce significant creativity, and that ability to create a creative product depends on the motivation and temperamental characteristics of the creative individual, and lists the skill characteristics that characterize creativity as the ability to see problems, fluency of thought, the flexibility of thought, originality, redefining and processing (Yavuzer, 1989, pp. 14- 15). 
Wilson, Guilford, and Christensen (As cited in Tarman, 2006, p. 116) specifies the following criteria to evaluate the quality of a creative product: An answer is original to the extent that it is uncommon in the target audience, to the extent that it is more skillful than the group of judges, and to the extent that it can bring together the most distant elements of knowledge and experience. Lowenfeld et al., who set the criteria for creativity (1962), state that creative features in art fields consist of flexibility, fluency, originality, sensitivity to problems, redefinition and arrangement, analysis, synthesis, and organization (As cited in Yavuzer, 1989, p. 35). Original thinking is the most noticeable, easily perceived, and reflected dimension of creativity, among other dimensions (Orhon, 2014, p. 34).

It is important for teachers, one of the essential factors of educations, to have the creative qualities for individuals to express themselves through music and improve their potentials for creativity. Teachers can create a learning environment to guide students towards creativity and its improvement if they have the quality of creativeness; in other words, the skill of flexible, smooth, and genuine thinking. (Yenilmez \& Yolcu, 2007, pp. 97- 98) Training music teachers who have creative thinking skills can be supported and improved through the skill of improvisation, which can be improved by playing instruments along with the vocational training they receive. Therefore, teachers who were educated in this direction and improved their improvisation skills can improve students' creative thinking skills by widening their horizons. Nevertheless, the level of improvisation and creative thinking skills of the teachers and the description of the reflection of those to each other is important.

In this context, answers to these questions were sought in this study, which aims to determine the reflections of pre-service music teachers' creative thinking skills on their instrumental improvisation ability:

Do the creative thinking skill levels of pre-service music teachers differ according to gender, secondary education institution they graduated from, or the period they received piano training?

Do the improvisation skill levels of pre-service music teachers on piano differ according to sex, secondary education institution they graduated from, or the period they received piano training?

What is the statistical level of the connection between the pre-service music teachers' creative thinking skills and levels of improvisation skills on the piano?

How is the creative learning environment of pre-service music teachers in piano lessons?

What are the opinions of pre-service music teachers on instrumental improvisation?

\section{Method}

\section{Research Model}

In this study mixed-method, convergence model was used. A mixed-method study is one in which the researcher incorporates both qualitative and quantitative methods of data collection and analysis in a single study. In the convergence model, the researcher collects both qualitative and quantitative data and then examines both data to determine the findings of a study (Creswel, 1999, p.455, 463).

"Correlational survey model" of quantitative research methods and "interview" method of qualitative research methods were used in the study. Relational analyses were obtained through correlational-type relations. In correlation-type relationship searches, it is tried to determine whether the variables overleap with each other (Karasar, 2006, p. 82). The interview method, which is one of the qualitative research techniques, is "a mutual and interactive communication process based on a predetermined and serious purpose, questioning and answering style" (Steward and Cash, 1985, as cited in Yıldırım and Şimşek, 2016, p. 129). 


\section{Research Group}

The research group consists of a total of 31 th grade students studying in Dokuz Eylul University Buca Faculty of Education, Department of Fine Arts, Music Education Department (DEU BFE, DFA MED) in the 2015-2016 academic year, 18 of which are women and 13 men. The improvisation skill levels of pre-service music teachers were limited to the piano in the study.

27 of the students from the research group were graduated from fine arts high school, 4 from other high schools. 4 of these students stated that they have been playing piano for four years, 22 of them for eight years and, 5 of them for more than eight years.

\section{Data Collection Tools}

Sounds and Images IIA form, Verbal A form, observation form, and creativity based learning environment scale were used to collect qualitative data and a semi-structured interview form for improvisation was used for quantitative data. The data collection tools are shown in figure 1 were used respectively.

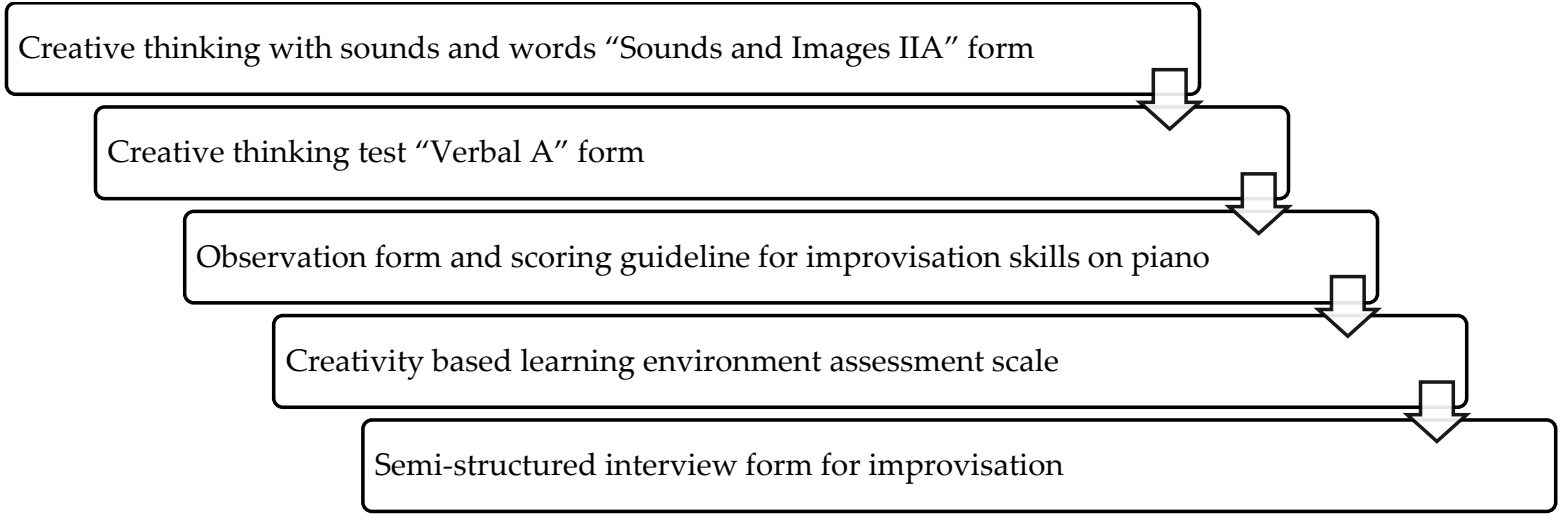

Figure 1. Data collection tools

Creative thinking with sounds and words "Sounds and Images IIA" form. The form consists of two independent tests: "Sounds and Images" and "Onomatopoeic (reflective) Words and Images," in which the degree of creativity is evaluated by the responses to auditory stimuli. Sounds and Images were developed by Torrance and Cunnington. The test is a useful and functional measurement tool that measures the original thinking potential of children, teenagers, and adults (Khatena ve Torrance, 1998, p. I).

In the reliability-validity study of the Turkish form conducted by Kaya and Bilen (2017). Language validity study was conducted in the academic year 2014-2015 by Dokuz Eylül University Buca Education Faculty Department of Foreign Language Education and Literature Faculty Department of Translation and Interpreting 4. Grade students $(\mathrm{n}=55)$. For the reliability and validity study, the Sounds and Images IIA Turkish form was conducted in the academic year 2014-2015 by Dokuz Eylül University, Adnan Menderes University, Muğla Sıtkı Koçman University Education Faculty Department of music Education 1.4. Grade students ( $\mathrm{n}=276$ ). The Cronbach's Alpha coefficient was found to be .61 . According to the confirmatory factor analysis results, the ratio between chi-square and degrees of freedom (x2/df) was found to be 1.73. The fit index values are RMSEA: .05, NFI: .97, NNFI: .96, CFI: .99, GFI: .99 and AGFI: .97.

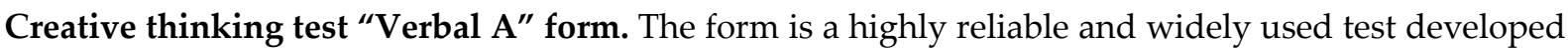
by Torrance in 1966. The verbal form, which can be used in a wide range of levels from 1st grade of primary school to adulthood (6 to 18 years old) (TTCT, http://www.ststesting.com/ngifted.html).

The Turkish language equivalence, reliability, and validity studies of the test were carried out by Aslan (2001). Primary school group means scores of the Verbal Form were obtained for the lowest originality $(\mathrm{n}=$ 
144), the highest fluency $(\mathrm{n}=144)$ dimensions. High school group means scores were obtained for the lowest flexibility $(n=116)$ and the highest fluency $(n=116)$ dimensions. University group mean scores were obtained for the lowest flexibility $(n=248)$ and the highest fluency $(n=248)$ dimensions. According to Spearman-Brown, Guttmann, and Cronbach Alpha internal consistency analyses, correlation coefficients were valued between .38 and .89. It is stated that the test is reliable for all age groups and all score types and that the subtests measure the expected dimensions of creative thinking as a result of the item total, item exclusion, and item discrimination analyzes conducted for the validity studies of the test (Aslan, 2001, pp. 26-30).

Observation form and scoring guideline for improvisation skills on the piano. The form was developed to reveal pre-service music teachers' improvisation skill levels on piano. While creating the Scoring Guideline for Improvisation Skills on Piano, the item pool was formed by scanning the literature, and a form draft was made. The form was rearranged after expert opinions were consulted. The pilot scheme of the guideline was conducted with randomly selected five students who were $3^{\text {rd }}$-grade students at the DEU BFE, DFA MED. In accordance with the expert opinions obtained after the pilot scheme, the guideline took its final form.

Observation guideline is developed and used for observation and in order to make the recording (digitizing) of the data easier if required (Borg, 1963, as cited in Karasar, 2006, p. 159). Observation guidelines may differ according to the topic and purpose of the observation. Guidelines can be made in such a way that the unit to be observed, the presence or absence is marked, the repetition or amount of the different symptoms of what is observed will be written, or the symptoms will be evaluated according to a graded scale (Karasar, 2006, p. 159).

Scoring guideline consists of instructions and observation form. Improvisation Skill Observation Form (ISOF) was made for grading the feedback given the instructions. The Piano Improvisation Instruction Form consists of eight different instructions that lead to improvisation based on some ideas, such as creating melodic answer sentences to the given rhythmic and melodic questions, playing scales musically, creating variations from the given themes.

For the ISOF, a scoring scheme with a score rating from 0 to 3 , including separate features for each category, has been stipulated taking the feedback given for each of the eight instructions in the instructions form into consideration in terms of rhythm, dynamic, measure, and tempo, tonality, and harmony, melody categories. While 0 points represent the feedback that can be considered ordinary in the scoring, 3 points represent the feedback with original quality.

After the scoring is done in line with the categories of the rhythm, dynamic, measure, and tempo, tonality and harmony, melody for each instruction, the highest score of improvisation ability that can be achieved with the ISOF was calculated as 105.

For the reliability studies of the forms developed in order to observe the improvisation skills on piano, a video recording of the application was made, and the improvisation performances were observed and evaluated by three observers in accordance with the scoring guideline. Kendall's W analysis was done for the reliability of the scoring. Kendall's coefficient of concordance results for the ISOF and categories of rhythm, dynamic, measure, and tempo, tonality and harmony, melody in the form are in table 1.

Table 1. Kendall's W coefficient of concordance results

\begin{tabular}{llllll}
\hline \multicolumn{1}{c}{ Categories } & $\mathbf{n}$ & $\mathbf{W}$ & $\boldsymbol{x}^{2}$ & $\mathbf{s d}$ & $\mathbf{p}$ \\
\hline Rhythm & 3 & $.79^{* *}$ & 71.48 & 30 & .00 \\
\hline Dynamic & 3 & $.61^{* *}$ & 54.42 & 30 & .00 \\
\hline Meter and tempo & 3 & $.62^{* *}$ & 55.59 & 30 & .00 \\
\hline Tonality and harmony & 3 & $.73^{* *}$ & 65.75 & 30 & .00 \\
\hline
\end{tabular}




\begin{tabular}{llllll} 
Melody & 3 & $.70^{* *}$ & 63.27 & 30 & .00 \\
\hline General improvisation skill & 3 & $.86^{* *}$ & 77.29 & 30 & .00 \\
\hline${ }^{* *} \mathrm{p}<.01$ & & & & &
\end{tabular}

Kendall's $\mathrm{W}$ takes a value between 0 and 1 , and the closer it is to 1 , the higher the concordance is. According to table 1, there is a statistically significant concordance between the evaluations by three different evaluators based on categories and the general ISOF [p<.01]. Cronbach's Alpha Reliability Coefficient of the ISOF, on the other hand, was calculated as $.92[.60 \leq \alpha<.90]$. In line with Kendall's W and Cronbach's Alpha Reliability form, it can be said that ISOF is a valid and reliable measurement tool.

Creativity based learning environment assessment scale. The scale was developed by Kaya and Bilen (2016), for the description of the creative learning environment of instrument lessons given at Education Faculties of Music education departments. The scale was developed as 5 points Likert scale and was applied to 528 students who were studying in the Faculty of Education, Fine Arts Education, Music Education Department in several universities during the 2012-2013 academic year. The scale's Cronbach Alpha reliability coefficient is .928. Confirmatory factor analysis showed that the scale has an acceptable level of fit index in general [ $x^{2} / \mathrm{sd}$ : 4.0; RMSEA: .07; NNFI: .98; CFI: .98; GFI: .94]. The scale includes factors of supporting a positive learning environment and creativity. The scale was used in order to reveal whether or not the students had creative learning environments for piano lessons.

Semi-structured interview form for improvisation. The form was made in order to understand the opinions of students about improvisation. The aim of the interview is to determine the parallelism and difference between the opinions of the interviewed individuals and to make comparisons accordingly (Brannigan, 1985, as cited in Yildirim and Simsek, 2016, p. 130). "Semi-structured interviews combine both fixed-alternative answering and ability to go deep in the relevant field." (Büyüköztürk et al., 2014, p. 152).

\section{Analysis of the Data}

In the analysis of the quantitative data of the study, frequency, percentage, mean, standard deviation, Cronbach Alpha reliability coefficient, Kolmogorov-Smirnov normality test, the point biserial correlation, and simple linear correlation (pearson moment product correlation) analysis were used. Statistical Package for the Social Science 22.0 statistical analysis program was used for these processes. Content analysis was made in the analysis of the qualitative data of the research.

\section{Findings}

\section{Creative Thinking Sounds and Images IIA Form Findings}

The result of the Kolmogorov-Smirnov normality test, which was applied to test whether the data obtained from the Sounds and Images IIA form show normal distribution, was calculated as .11, and the pvalue was calculated as .20. It can be said that the scores of the students on the Sounds and Images IIA form are normally distributed [ $p>05]$. Cronbach Alpha reliability coefficient of the scores was calculated as .60. This result shows that the measurement is reliable $[.60 \leq \alpha<.90]$.

The distribution of the scores of the students according to their gender, the high school they graduated from, and the duration of piano education is given in the crosstab in table 2. The highest score that can be obtained with the Sounds and Images IIA form is 48 . The scores obtained by the students were transformed into categorical variables with $0-9,10-18,19-27,28-36,37-48$ points for the crosstab. The crosstab gives the frequency and percentage distribution of the participants in the study, according to two or more categorical variables (Büyüköztürk, 2009, p. 27). 
Table 2. Distribution of Sounds and Images IIA form scores by gender, graduated high school, and period of piano training

\begin{tabular}{|c|c|c|c|c|c|c|c|c|c|c|c|c|}
\hline \multirow[b]{2}{*}{ Gender } & \multicolumn{2}{|c|}{$\begin{array}{c}\text { 0-9 } \\
\text { Points }\end{array}$} & \multicolumn{2}{|c|}{$\begin{array}{c}\text { 10-18 } \\
\text { Points }\end{array}$} & \multicolumn{2}{|c|}{$\begin{array}{c}\text { 19-27 } \\
\text { Points }\end{array}$} & \multicolumn{2}{|c|}{$\begin{array}{c}\text { 28-36 } \\
\text { Points }\end{array}$} & \multicolumn{2}{|c|}{$\begin{array}{c}\text { 37-48 } \\
\text { Points }\end{array}$} & \multicolumn{2}{|c|}{ Total } \\
\hline & $n$ & $\%$ & $\mathbf{n}$ & $\%$ & $\mathbf{n}$ & $\%$ & $\mathbf{n}$ & $\%$ & $\mathbf{n}$ & $\%$ & $\mathbf{n}$ & $\%$ \\
\hline Women & 1 & 3.2 & 7 & 22.6 & 5 & 16.1 & 5 & 16.1 & 0 & 0 & 18 & 58 \\
\hline Men & 3 & 9.7 & 6 & 19.4 & 3 & 9.7 & 1 & 3.2 & 0 & 0 & 13 & 42 \\
\hline Total & 4 & 12.9 & 13 & 41.9 & 8 & 25.8 & 6 & 19.4 & 0 & 0 & 31 & 100 \\
\hline High school & $\mathbf{n}$ & $\%$ & $\mathbf{n}$ & $\%$ & $\mathbf{n}$ & $\%$ & $\mathbf{n}$ & $\%$ & $\mathbf{n}$ & $\%$ & $\mathbf{n}$ & $\%$ \\
\hline Fine arts & 3 & 9.7 & 12 & 38.7 & 7 & 22.6 & 5 & 16.1 & 0 & 0 & 27 & 87.1 \\
\hline Others & 1 & 3.2 & 1 & 3.2 & 1 & 3.2 & 1 & 3.2 & 0 & 0 & 4 & 12.9 \\
\hline Total & 4 & 12.9 & 13 & 41.9 & 8 & 25.8 & 6 & 19.4 & 0 & 0 & 31 & 100 \\
\hline $\begin{array}{l}\text { Period of piano } \\
\text { training }\end{array}$ & $\mathbf{n}$ & $\%$ & $\mathbf{n}$ & $\%$ & $\mathbf{n}$ & $\%$ & $\mathbf{n}$ & $\%$ & $\mathbf{n}$ & $\%$ & $\mathbf{n}$ & $\%$ \\
\hline 4 years & 1 & 3.2 & 1 & 3.2 & 1 & 3.2 & 1 & 3.2 & 0 & 0 & 4 & 12.9 \\
\hline 8 years and more & 3 & 9.7 & 12 & 38.7 & 7 & 22.6 & 5 & 16.1 & 0 & 0 & 27 & 87.1 \\
\hline Total & 4 & 12.9 & 13 & 41.9 & 8 & 25.8 & 6 & 19.4 & 0 & 0 & 31 & 100 \\
\hline
\end{tabular}

According to the data in table 2, 1 of the 4 people from the research group who scored between 0 and 9 were women, 3 men. 3 of them graduates of fine arts high schools, 1 of them other high schools. 1 of them has been playing the piano for four years, 3 of them eight years and more. The 13 people who score between 1018, 7 are women and, 6 are men, 12 graduates of fine arts high schools, 1 of them other high schools. 1 of them has been playing the piano for four years, 12 of them eight years and more. The 8 people who score between 19-27, 5 are women, and 3 are men, 7 graduates from fine arts high schools and, 1 from other high schools. 1 of these students has been playing the piano for four years, 7 for eight years. The 6 people who score between 28-36, 5 are women, 1 man, 5 graduates of fine arts high schools, 1 from other high schools. 1 of them has been playing the piano for four years, 5 of them eight years and more. There are no students with scores between $37-48$.

Correlation analysis was conducted to test the significance of the correlation between the scores of the students on the Sounds and Images IIA form and their genders, the high schools they graduated from, and the periods of piano training.

The strength of a correlation is described through the amount of correlation between the variables. While a strong correlation requires a consistent or close $Y$ value depending on the $X$ value, the $Y$ value, which does not correspond to or is close to the $X$ value, indicates the weakness of the correlation. Therefore, the variability of $\mathrm{Y}$ scores corresponding to each $\mathrm{X}$ increases, and the correlation coefficient approaches zero (Elifson, Runyon, and Haber, 1990 and Heiman, 1996, as cited in Çokluk et al., 2012, p. 52). The point biserial correlation is the value of Pearson's product moment correlation when one of the variables is dichotomous and the other variable is metric (Kornbrot, 2005, p. 1553).

The results of the point biserial correlation analysis conducted to reveal whether there is a correlation between the students' Sounds and Images IIA form and their genders, high schools, and the periods of piano training are included in table 3. 
Table 3. Correlation results of Sounds and Images IIA form scores

\begin{tabular}{lccc}
\hline & $\mathbf{n}$ & $\mathbf{r}$ & $\mathbf{P}$ \\
\hline Gender & 31 & -.27 & .07 \\
\hline High school & 31 & .09 & .32 \\
\hline Period of piano training & 31 & -.09 & .31 \\
\hline
\end{tabular}

According to the correlation analysis data in table 3, there is a negative and low level of correlation between the Sounds and Images IIA form scores and gender. This correlation is not statically significant $[\mathrm{r}=\mathrm{-}$ .27; $p>$.01]. The positive, low-level correlation between the "Sounds and Images IIA" form scores and the high school graduated from is not statistically significant $[\mathrm{r}=.09 ; \mathrm{p}>.01]$. The correlation between the Sounds and Images IIA form scores and the period of piano training is negative, low, and not statistically significant $[\mathrm{r}=-$ $.15 ; \mathrm{p}>.01]$.

This result can be interpreted as the research group revealed that there was no correlation between gender, high school and period of piano training, and creative thinking levels in the context of "Sounds and Images IIA" form scores.

\section{Findings of the Creative Thinking Test Verbal A Form}

The result of the Kolmogorov-Smirnov normality test, which was applied to test whether the data obtained with the Verbal A Form show normal distribution, is given in table 4.

\begin{tabular}{lccc}
\hline & Kolmogorov-Smirnov & sd & p \\
\hline Fluency & .12 & 31 & .20 \\
\hline Flexibility & .13 & 31 & .17 \\
\hline Originality & .10 & 31 & .20 \\
\hline General & .07 & 31 & .20 \\
\hline p $>.05$ & & &
\end{tabular}

According to the data in table 4, it can be said that the scores the students got with the Verbal A form show the normal distribution in terms of fluency, flexibility, originality dimensions, and general form [p $>$.05].

The Cronbach Alpha reliability coefficient for the Verbal A form was calculated as .84. This result shows that the measurement is quite reliable $[.60 \leq \alpha<.90]$.

The distribution of the scores of the students in terms of gender, the high school they graduated from, and the period of piano training are given in the crosstab in table 5. The highest score that can be obtained with the Verbal A form is 200. Therefore, the scores obtained by the students were transformed into categorical variables with 0-40, 41-80, 81-120, 121-160, and 161-200 score intervals for the crosstab.

Table 5. Distribution of Verbal A form scores by gender, graduated high school, and period of piano training

\begin{tabular}{|c|c|c|c|c|c|c|c|c|c|c|c|c|}
\hline \multirow[b]{2}{*}{ Gender } & \multicolumn{2}{|c|}{$\begin{array}{c}\text { 0-40 } \\
\text { Points }\end{array}$} & \multicolumn{2}{|c|}{$\begin{array}{l}41-80 \\
\text { Points }\end{array}$} & \multicolumn{2}{|c|}{$\begin{array}{l}81-120 \\
\text { Points }\end{array}$} & \multicolumn{2}{|c|}{$\begin{array}{l}\text { 121-160 } \\
\text { Points }\end{array}$} & \multicolumn{2}{|c|}{$\begin{array}{l}\text { 161-200 } \\
\text { Points }\end{array}$} & \multicolumn{2}{|c|}{ Total } \\
\hline & $\mathbf{n}$ & $\%$ & $\mathbf{n}$ & $\%$ & $\mathbf{n}$ & $\%$ & $\mathrm{n}$ & $\%$ & $\mathrm{n}$ & $\%$ & $\mathbf{n}$ & $\%$ \\
\hline Women & 0 & 0 & 12 & 38.7 & 6 & 19.4 & 0 & 0 & 0 & 0 & 18 & 58 \\
\hline Men & 0 & 0 & 4 & 12.9 & 8 & 25.8 & 1 & 3.2 & 0 & 0 & 13 & 42 \\
\hline Total & 0 & 0 & 16 & 51.6 & 14 & 45.2 & 1 & 3.2 & 0 & 0 & 31 & 100 \\
\hline High school & $\mathbf{n}$ & $\%$ & $\mathbf{n}$ & $\%$ & $\mathbf{n}$ & $\%$ & $\mathbf{n}$ & $\%$ & $\mathbf{n}$ & $\%$ & $\mathbf{n}$ & $\%$ \\
\hline Fine arts & 0 & 0 & 15 & 48.4 & 12 & 38.7 & 0 & 0 & 0 & 0 & 27 & 87.1 \\
\hline Others & 0 & 0 & 1 & 3.2 & 2 & 6.5 & 1 & 3.2 & 0 & 0 & 4 & 12.9 \\
\hline Total & 0 & 0 & 16 & 51.6 & 14 & 45.2 & 1 & 3.2 & 0 & 0 & 31 & 100 \\
\hline $\begin{array}{l}\text { Period of pia } \\
\text { training }\end{array}$ & n & $\%$ & n & $\%$ & $\mathbf{n}$ & $\%$ & $\mathbf{n}$ & $\%$ & $\mathbf{n}$ & $\%$ & $\mathbf{n}$ & $\%$ \\
\hline
\end{tabular}




\begin{tabular}{lcccccccccccc}
4 years & 0 & 0 & 1 & 3.2 & 2 & 6.5 & 1 & 3.2 & 0 & 0 & 4 & 12.9 \\
\hline 8 years and more & 0 & 0 & 15 & 48.4 & 12 & 38.7 & 0 & 0 & 0 & 0 & 27 & 87.1 \\
\hline Total & 0 & 0 & 16 & 51.6 & 14 & 45.2 & 1 & 3.2 & 0 & 0 & 31 & 100 \\
\hline
\end{tabular}

According to the data in table 5, the scores of the research group range between 41 and 160 of the 16 people scoring between 41 and 80, 12 are women, and 4 are men, 15 graduates from fine arts high schools, and 1 from other high schools. 1 of these students has been playing the piano for four years, and 15 eight years and more. Of the 14 people scoring between 81 and 120, 6 are women, and 8 are men, 12 of them are graduates of fine arts high schools, and 2 of other high schools. 2 of these students have been playing the piano for four years, and 12 eight years and more. The person who scored between 121 and 160 is a men student who is a graduate of other high schools and has been playing the piano for four years.

The results of the simple linear correlation analysis performed to reveal whether there is a correlation between the students' Verbal A form scores and their gender, high school, and period of piano training are included in table 6.

Table 6. Correlation results of Verbal A form scores

\begin{tabular}{lccc}
\hline & $\mathbf{n}$ & $\mathbf{r}$ & $\mathbf{p}$ \\
\hline Gender & 31 & .03 & .44 \\
\hline High school & 31 & $.33^{*}$ & .04 \\
\hline Period of piano training & 31 & $-.30^{*}$ & .05 \\
\hline${ }^{*} \mathrm{p}<.05$. & & &
\end{tabular}

According to the correlation analysis data in table 6, there is a positive and statistically significant correlation between the scores of the Verbal A form and the high school graduated from [ $\mathrm{r}=.33$; $\mathrm{p}<.05]$, negative and statistically significant correlation between the scores of the Verbal A form and the period of piano training [ $r=-.30 ; p>.05]$. The positive and low-level correlation between Verbal A form scores and gender is not statistically significant $[\mathrm{r}=.03 ; \mathrm{p}>$.05].

\section{Findings of the ISOF}

The Cronbach Alpha reliability coefficient of the ISOF, which was developed to determine the skill levels of pre-service music teachers by revealing the creative side of their improvisation skills on the piano, was calculated as .92. This result shows that the measurement is quite reliable $[.60 \leq \alpha<.90]$.

The distribution of the scores obtained by the students with the ISOF in terms of gender, the high school they graduated from, and the period of piano training are given in the crosstab in table 7 . The highest score that can be obtained with the ISOF is 105 . The scores obtained by the students were transformed into categorical variables with a range of $0-21,22-42,43-63,64-84,85-105$ for the crosstab.

Table 7. Distribution of improvisation skills observation form scores by gender, graduated high school, and period of piano training

\begin{tabular}{|c|c|c|c|c|c|c|c|c|c|c|c|c|}
\hline \multirow[b]{2}{*}{ Gender } & \multicolumn{2}{|c|}{$\begin{array}{c}\text { 0-21 } \\
\text { Points }\end{array}$} & \multicolumn{2}{|c|}{$\begin{array}{c}22-42 \\
\text { Points }\end{array}$} & \multicolumn{2}{|c|}{$\begin{array}{c}43-63 \\
\text { Points }\end{array}$} & \multicolumn{2}{|c|}{$\begin{array}{c}\text { 64-84 } \\
\text { Points }\end{array}$} & \multicolumn{2}{|c|}{$\begin{array}{l}\text { 85-105 } \\
\text { Points }\end{array}$} & \multicolumn{2}{|c|}{ Total } \\
\hline & n & $\%$ & $\mathbf{n}$ & $\%$ & $\mathbf{n}$ & $\%$ & $\mathbf{n}$ & $\%$ & $\mathrm{n}$ & $\%$ & $\mathbf{n}$ & $\%$ \\
\hline Women & 0 & 0 & 12 & 38.7 & 6 & 19.4 & 0 & 0 & 0 & 0 & 18 & 58 \\
\hline Men & 0 & 0 & 4 & 12.9 & 8 & 25.8 & 1 & 3.2 & 0 & 0 & 13 & 42 \\
\hline Total & 0 & 0 & 16 & 51.6 & 14 & 45.2 & 1 & 3.2 & 0 & 0 & 31 & 100 \\
\hline High school & $\mathbf{n}$ & $\%$ & $\mathbf{n}$ & $\%$ & $\mathbf{n}$ & $\%$ & $\mathbf{n}$ & $\%$ & n & $\%$ & $\mathbf{n}$ & $\%$ \\
\hline Fine arts & 0 & 0 & 15 & 48.4 & 12 & 38.7 & 0 & 0 & 0 & 0 & 27 & 87.1 \\
\hline Others & 0 & 0 & 1 & 3.2 & 2 & 6.5 & 1 & 3.2 & 0 & 0 & 4 & 12.9 \\
\hline Total & 0 & 0 & 16 & 51.6 & 14 & 45.2 & 1 & 3.2 & 0 & 0 & 31 & 100 \\
\hline
\end{tabular}


Period of piano

\begin{tabular}{|c|c|c|c|c|c|c|c|c|c|c|c|c|}
\hline training & $\mathbf{n}$ & $\%$ & $\mathbf{n}$ & $\%$ & $\mathbf{n}$ & $\%$ & $\mathbf{n}$ & $\%$ & $\mathbf{n}$ & $\%$ & $\mathbf{n}$ & $\%$ \\
\hline 4 years & 0 & 0 & 1 & 3.2 & 2 & 6.5 & 1 & 3.2 & 0 & 0 & 4 & 12.9 \\
\hline 8 years and more & 0 & 0 & 15 & 48.4 & 12 & 38.7 & 0 & 0 & 0 & 0 & 27 & 87.1 \\
\hline Total & 0 & 0 & 16 & 51.6 & 14 & 45.2 & 1 & 3.2 & 0 & 0 & 31 & 100 \\
\hline
\end{tabular}

The scores are listed according to the data in table 7 range between 22 and 84 . of the 16 people from the research group, who scored between 22 and 42, 12 are women, and 4 are men, 15 are graduates from fine arts high schools, 1 from other high schools. 1 of these students has been playing the piano for four years, 15 for eight years, and more. 14 people from the research group, who got between 43 and 63 points, 6 are women, and 8 are men, 12 were graduates of fine arts high schools, 2 from other high schools. 2 of these students have been playing piano for four years, 12 for eight years, and more. The men student who scored between 64-84 is another high schools graduate and has been playing the piano for four years.

According to the scores obtained by the students with the ISOF, the significance of the correlation in the context of gender, graduation from high school, and duration of piano education was calculated by correlation analysis. However, since the ISOF data did not show a normal distribution by showing excessively positive skewness (skewness coefficient $=3.73$ ), correlation analysis was performed after the logarithmic transformation in this data set.

In case the scores show excessive deviation from the normal, if the researcher wants to use statistics that require normality, he/she can redefine the data with a different unit by converting the scores into a new distribution. If there is an excessive positive skewness that is not suitable for the normal, the points are converted to a new distribution by logarithmic transformation (Büyüköztürk, 2009, p. 42- 43). After the logarithmic transformation, the result of the Kolmogorov-Smirnov normality test, which was applied to test whether the data set showed normal distribution, was calculated as .09, and the p-value was calculated as .20. Therefore, the new data set has a normal distribution [ $p>.05]$.

The results of the simple linear correlation analysis performed to reveal whether there is a correlation between the ISOF and the gender of the students, the high school they graduated from, and their period of piano training are included in table 8.

Table 8. Correlation results of ISOF scores

\begin{tabular}{llll}
\hline & $\mathbf{n}$ & $\mathbf{r}$ & $\mathbf{p}$ \\
\hline Gender & 31 & .01 & .48 \\
\hline High school & 31 & $.36^{*}$ & .02 \\
\hline Period of piano training & 31 & $-.30^{*}$ & .05 \\
\hline${ }^{*} \mathrm{p}<.05$ & & &
\end{tabular}

According to the correlation analysis data in table 8 , there is a positive and significant correlation between improvisation skill and graduated high school $[\mathrm{r}=.36 ; \mathrm{p}<.05]$ There is a negative and significant correlation between improvisation skills and the period of piano training $[\mathrm{r}=-.30$; $\mathrm{p}<.05]$. The correlation between improvisation skills and gender is not statistically significant [ $r=.01 ; \mathrm{p}>.05]$.

\section{Correlation Findings of Improvisation Skills Observation Form, Sounds and Images IIA Form and Verbal}

\section{A Form Scores}

According to the scores of the students, the significance test of the correlation between the ISOF and the Sounds and Images IIA and Verbal A forms was performed with Pearson product-moment correlation analysis. The results of the analysis are included in table 9. 
Table 9. Correlation results of ISOF scores

\begin{tabular}{lccc}
\hline & $\mathbf{n}$ & $\mathbf{r}$ & $\mathbf{p}$ \\
\hline Sounds and Images IIA & 31 & .14 & .46 \\
\hline Verbal A & 31 & .14 & .46 \\
\hline
\end{tabular}

According to the data in table 9, the correlation coefficient between the ISOF and Sounds and Images IIA form scores was found as .14. Therefore, the correlation between the means of the students' scores is positive, low, and not statistically significant [p>.01]. The correlation coefficient between the Improvisation Skill and the Verbal A form scores was found as .14. The correlation between the means of the students' scores is positive, low, and not statistically significant [p>.01].

\section{Findings of the Creativity Based Learning Environment Assessment Scale}

The Kolmogorov-Smirnov normality test p-value of the data obtained from the answers given by the research group in the context of the piano lesson to the Creativity Based Learning Environment Assessment Scale is .20. This value shows that the data have an ideal normal distribution [p>.05]. The Cronbach's Alpha reliability coefficient of the students' answers was found to be .87 . This result shows that the measurement is very reliable $[.60 \leq \alpha<.90]$.

The distribution of the answers given to the scale according to the positive learning environment, the dimensions of supporting creativity, and the general scale averages are given in table 10.

Table 10. Distribution of the answers given to the creativity based learning environment assessment scale

\begin{tabular}{lcccccccc} 
& & \multicolumn{2}{c}{$\begin{array}{c}\text { Positive Learning } \\
\text { Environment }\end{array}$} & \multicolumn{2}{c}{ Supporting Creativity } & \multicolumn{2}{c}{ General } \\
\cline { 2 - 9 } \multicolumn{1}{c}{ Gender } & $\mathbf{n}$ & $\overline{\boldsymbol{x}}$ & $\mathbf{\%}$ & $\overline{\boldsymbol{x}}$ & $\mathbf{\%}$ & $\overline{\boldsymbol{x}}$ & $\mathbf{\%}$ \\
\hline Women & 18 & 3.18 & 63.6 & 2.42 & 48.4 & 2.73 & 54.6 \\
\hline Men & 13 & 3.74 & 74.8 & 3.02 & 60.4 & 3.32 & 66.4 \\
\hline Total & 31 & 3.41 & 68.2 & 2.67 & 53.4 & 2.98 & 59.6 \\
\hline
\end{tabular}

According to the data in Table 10, it is seen that in piano lessons, a positive learning environment is provided at a rate of $68 \%$, support for creativity at a rate of $53.4 \%$, and a learning environment that supports creativity at a rate of $59.6 \%$.

\section{Findings of Semi-Structured Interview Form for Improvisation}

All of the students interviewed $(n=31)$ have not participated in an improvisation activity on the piano before.

Findings regarding the questions "In which courses are the activities on improvisation included? (Can you speak of the activities if they are included?) are in table 11.

Table 11. Distributions of answers given to the question "In which courses are the activities on improvisation included?"

\begin{tabular}{lccll}
\hline Categories & $\mathbf{f}$ & $\mathbf{\%}$ & \multicolumn{2}{c}{ Examples of expressions } \\
\hline Special teaching methods course & 26 & 44.8 & $\begin{array}{l}\text { We were doing improvisation on a pentatonic scale or } \\
\text { rhythmically. }\end{array}$ \\
\hline $\begin{array}{l}\text { Harmony-counterpoint accompaniment } \\
\text { course }\end{array}$ & 2 & 3.4 & $\begin{array}{l}\text { We learned how to accompany variations while } \\
\text { accompanying school songs. }\end{array}$ \\
\hline Solo instrument course & 4 & 6.9 & $\begin{array}{l}\text { While my teacher performs chord transitions in the guitar } \\
\text { lesson, I make melodic transitions remaining in tone. }\end{array}$ \\
\hline Accompaniment Course & 5 & 8.6 & $\begin{array}{l}\text { We would accompany by composing chords suitable for the } \\
\text { given piece. }\end{array}$ \\
\hline Electronic organ course & 5 & 8.6 & \begin{tabular}{l} 
We gained insight into chords, different tones. \\
\hline
\end{tabular}
\end{tabular}




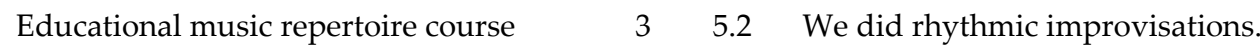

\begin{tabular}{lccll}
\hline Play, dance, and music course & 2 & 3.4 & We did improvisational dances. \\
\hline Not included in any class. & 11 & 19 & We did really not do improvisation activities. \\
\hline Total & 58 & 100 & \\
\hline
\end{tabular}

According to the distribution of answers of students given to the question "In which courses are the activities on improvisation included?" it is seen that activities on improvisation are mostly used in the Special Teaching Methods course $(\mathrm{f}=26)$. On the other hand, it is stated that no activities on improvisation were included in any lesson $(\mathrm{f}=11)$.

Findings regarding the question "Do you do activities on improvisation in piano lessons? (If so, what are those studies?) are in table 12.

Table 12. Distribution of answers given to the question "Do you do activities on improvisation in piano lessons?"

\begin{tabular}{lccl}
\hline \multicolumn{1}{c}{ Categories } & f & $\mathbf{\%}$ & \multicolumn{1}{c}{ Statement examples } \\
\hline No & 30 & 96.8 & We generally work depending on the note. \\
\hline Partly & 1 & 3.2 & Not specifically on improvisation, but I play my practices. \\
\hline Total & 31 & 100 & \\
\hline
\end{tabular}

According to findings regarding the question "Did you do activities on improvisation in piano lessons? (If so, what are those activities?) are in table 12 it is stated that improvisation activities were not included in piano lessons, that activities were studied depending on notes, that generally works were studied ( $\mathrm{f}=30)$, and along with that, that there were individual attempts on improvisation $(\mathrm{f}=1)$.

The findings regarding the question "What kind of gains do you think being able to improvisation on the piano will provide?" are given in table 13.

Table 13. Distribution of answers given to the question "What kind of gains do you think being able to improvisation on the piano will provide?"

\begin{tabular}{|c|c|c|c|}
\hline Categories & $\mathbf{f}$ & $\%$ & Statement examples \\
\hline Musical expression & 10 & 11.4 & It allowed me to render the work I am performing. \\
\hline Audience (hearing) & 3 & 3.4 & $\begin{array}{l}\text { Since improvisation is also connected to hearing, it contributed to } \\
\text { my hearing. }\end{array}$ \\
\hline $\begin{array}{l}\text { Instrument control and } \\
\text { accompaniment }\end{array}$ & 30 & 34.1 & $\begin{array}{l}\text { My control over the instrument increases. It also improves } \\
\text { accompaniment playing. }\end{array}$ \\
\hline Other courses & 2 & 2.3 & $\begin{array}{l}\text { If I were able to improvise, I would have been doing what I } \\
\text { desired, and that would have affected my other courses. }\end{array}$ \\
\hline The profession of teaching & 12 & 13.6 & $\begin{array}{l}\text { I would have taught my lessons more efficiently when I became a } \\
\text { teacher. }\end{array}$ \\
\hline Quality of the course and students & 7 & 8 & My students would have attended classes more actively. \\
\hline Happiness & 7 & 8 & I would have felt better since it also provides self-confidence. \\
\hline Creativity & 6 & 6.8 & I think improvisation is the first step in terms of creativity. \\
\hline Freedom & 10 & 11.4 & $\begin{array}{l}\text { Being able to play without depending on notes would be a good } \\
\text { communion. }\end{array}$ \\
\hline Fast thinking & 1 & 1.1 & Improvisation is just like talking, and that provides fast thinking. \\
\hline Total & 88 & 100 & \\
\hline
\end{tabular}

According to the findings regarding the question "What kind of gains do you think being able to improvisation on the piano will provide?" in table 13, it was stated that the most gain would be in instrument control and accompaniment $(\mathrm{f}=30)$. Besides, it was also stated that it would contribute to the profession of teaching $(f=12)$, expressing oneself musically $(f=10)$, and thinking fast $(f=10)$. 


\section{Conclusion and Discussions}

The results of the research on the reflection levels of the creative thinking skill levels of pre-service music teachers on their instruments (piano) and improvisation skills are considered:

The first result of the study is that the creative thinking levels of the pre-service music teachers are below the intermediate level. This result may have resulted from the fact that the research group was not adequately equipped with creativity, or the education they received was insufficient to support their creativity. Çevik's study (2004) also shows parallelism with this opinion. In this research carried out by Çevik regarding the competencies required for music teaching in the Undergraduate Program of the Department of Music Teaching, which came into force in 1998; it is stated that instructors, teachers, and students wanted and needed to make more use of technology in music education and to enrich their creativity in developing written, and/or visual teaching materials. Besides, he/she mentions that programs, including lessons for creativity, should be prepared.

The second result of the study is that there is a low level of correlation between the creative thinking levels of pre-service music teachers and gender, graduated high school, and the period of piano training. This result revealed that gender, graduated high school, and period of piano training did not affect the creative thinking skills of the research group within the scope of this study. Özben and Argun's study (2002) partially supports this result. While a significant correlation was found between the fluency and flexibility dimensions of creativity and gender in Özben and Argun's study, no significant correlation was found between the originality dimension and gender. The study of Batıbay and Piji (2006) supports the conclusion that there is no correlation between the level of creativity and the graduated high school. In the study of Batıbay and Piji, the creativity scores of pre-service teachers did not differ according to the type of high school they graduated from. These results constitute the opinion that studies for the development of creativity in fine arts high schools are not sufficiently included.

The third result of the study is that the improvisation skills of the pre-service music teachers are low. According to this result, it can be said that the research group was not sufficiently equipped in improvisation, the education they received was insufficient to support their creativity, or they did not have sufficient selfconfidence to improvisation. The opinions of the research group on improvisation also support this view about the reasons for this result.

Pre-service music teachers stated, for improvisation, that piano lessons do not include studies on improvisation, that works are generally studied in lessons and practices based on notes are carried out, besides, there is not much work on improvisation in lessons other than Special Teaching Methods. They stated that being able to improvise on the piano will provide gains in instrument mastery and accompaniment playing and will contribute to the profession of teaching, musical expression, and free-thinking. In addition, they stated that they felt inadequate in improvisation.

The studies of Otacıoglu (2006) and Çevik (2011) also support this view that the research group was not confident enough about improvisation. Otacıŏlu determined in his/her study, which examined the connection between musical perception and self-confidence of pre-service teachers who receive music education in institutions that train music teachers, and their schools and instrumental success levels, that selfconfidence affected instrumental success. Çevik included in his/her study presenting pre-service music teachers' views on accompaniment playing lesson and their suggestions on the issues they had difficulty in the lesson. It is stated that students have difficulty in accompaniment composing to a school song and, as a solution suggestion, that teachers should apply teaching methods where students will gain self-confidence with activities for developing creativity and be able to compose improvisation. 
The fourth result of the study is that there is a low level of correlation between improvisation skill levels of pre-service music teachers and gender, graduated high school, and period of piano training. This result revealed that gender, graduated high school, and the period of piano training did not affect the improvisation skills of the research group within the scope of this study. Considering the period of piano training of students who graduated from Fine Arts High school, and other high schools, the fact that their improvisation levels are low and that the graduated high school does not create a significant correlation with improvisation skills creates the idea that the education provided in Fine Arts High Schools does not support musical creativity.

The fifth result of the study revealed that there is a positive, low level, and statistically insignificant correlation between the creative thinking levels of the pre-service music teachers and their improvisation skill levels on the piano. This result may have resulted from the fact that the research group was insufficient in creativity and improvisation.

The reason for the research group's insufficiency in creativity and improvisation can be interpreted as that the education they received could not sufficiently support them in terms of creativity and improvisation. Studies of Kalkanoglu (2007, 13), Kalyoncu (2005), Görsev (2006), and Küpana (2013) state that courses taken can be effective in the development of creativity and improvisation skills.

Kalkanoğlu (2007: 13) states that the ability to improvisation accompaniment to a given melody is one of the most important features that a music teacher should have and that music teachers should have certain knowledge to be able to improvisational accompaniment. In his study, Kalyoncu (2005) dealt with the music teaching undergraduate programs changed within the scope of revising teacher training programs in education faculties within the scope of the National Education Development Project in 1998; He states that the courses aimed at teaching musical behaviors tend to be concentrated in the direction of making music (playing, singing, etc.), and that lessons for students to discover and develop their musical creativity should also be offered. It is also stated that since there is no course that allows improvisation in itself, improvisation activities within the scope of the Educational Music Composition and Accompaniment course can only encourage the development of musical creativity to a limited extent. Görsev (2006), in his/her study examining the relations between piano training, music theory and audition training and accompaniment lessons, and students' ability to create an improvised accompaniment to school songs, determined that students' academic success in these lessons and their ability to create an improvised accompaniment to school songs were at a moderate level in theoretical and practical dimensions. He/ she stated that the stand of the courses that affect the development of students' improvisation skills should be evaluated, and arrangements should be made. In his/her study examining the approaches that develop musical creativity, Küpana (2013) stated that the basic dimensions of musical creativity are composition and improvisation, and creativity is required to gain rendering skills in an instrument and vocal education. He/she stated that musical creativity requires proficiency in terms of melodic, rhythmic, and formal aspects, and therefore, efforts to develop a rich knowledge base in music education will be important in developing musical creativity.

The sixth result of the study is that pre-service music teachers are provided with a learning environment that supports creativity at an average level (providing a positive learning environment, supporting creativity) in piano lessons. It can be said that the low level of creative thinking and improvisation skill levels of the research group despite this result leads to the conclusion that they were inadequate in demonstrating or using these skills.

Another result of the study, for pre-service music teachers, is that the special teaching methods for improvisation and creative activities in play, dance, and music lessons are not enough to express themselves creatively; they only gain an idea about creativity in these lessons and have difficulty in transferring their limited experiences to other instruments or fields. 
The study of Batıbay and Piji (2006), which examined the correlation between the success of pre-service music teachers in music lessons and their musical creativity, revealed that students could not fully reflect their musical creativity to their success in music lessons.

The studies of Azzara (1992), Özer (2014), Kandemir (2009), Wright \& Kanellopolos (2010), and Güleç (2017) reveal that one can be adequately equipped on this subject with the training given on improvisation and that this education can support creativity.

Azzara (1992) revealed that the improvisation program and improvisation studies applied to examine the effects of improvisation techniques based on audition on the musical achievement of primary school instrument students increased the musical success of students. Özer (2014) revealed that the analysis level in piano training, sight-reading, and improvisation is developed with the 10-week training he/she created to determine the effect of analysis (harmony/form elements) supported regular exercises in piano lessons to sight-reading and improvisation skills of functional piano skills. Kandemir (2009), in her study on the effect of improvisation studies on the musical creativity process with the Orff Approach, revealed that after 6 weeks of music lessons based on improvisation activities, the level of musical creativity of students increased. Wright and Kanellopoulos (2010), in their study where they examined the effects of free improvisation course on the perceptions of pre-service teachers, revealed that teachers are important in developing teaching approaches in developing students' musical creativity and behaviors such as taking responsibility in music education. Güleç (2017) concluded that the 12-week planned improvisation activities, which were created to reveal the effects of improvisation practices in playing violin on students' musical creativity and violin performance, had positive effects on violin playing performance and improved the level of musical creativity.

\section{Suggestions}

Creativity can be defined as the individual generating new unique solutions by recognizing and questioning problems. Therefore, creativity is an action that has no boundaries and can be developed, and it can occur to different extents, in different areas and dimensions in each individual.

Creative individuals who are open, independent, more aware of their own inner world, who can develop new perspectives and judgments, explain the world in unique ways, who have developed in physical, psycho-social, and cognitive aspects and have acquired a positive identity will be able to affect the environment, society and culture, and therefore the country they live in positively.

Organizing creative learning environments in all areas of education will be an important factor in bringing up happy, independent, innovative, and creative individuals. In this regard, it is important for music teachers who are to guide through music education, which is one of the most suitable areas for the development of creative potential, to have creative education in the center of their training.

It can be said that instrument training in institutions that train music teachers mostly aims at improving technical and performance skills. However, it can be suggested that these lessons be organized in a way to train teachers who can use their instruments creatively and more effectively with various improvisations in music classes.

Considering the proficiency of music teaching, it is important that they are competent enough to fulfill the role and responsibilities expected from them, and therefore to reflect the pedagogical and creative transformations to the learning process.

Improvisation activities should be created that will enable the pre-service music teachers to reveal their creative potential and support their creativity and enable them to express themselves freely in a musical way and develop them in this sense. Improvisation studies will also contribute to music teacher candidates' aesthetic sensibility and their internalization of music by improving their musical skills. Creating activities on 
improvisation, including movement improvisations as well as instrumental improvisations, will support preservice music teachers to express themselves freely and creatively. Therefore, it can be suggested for university-level education to create or popularize course content in which creativity is supported in all courses, and pre-service teachers can transfer their creative potentials to various fields.

It can be suggested that this study should be re-conducted after the implementation of the activities or lessons planned for developing the creative potential of students and improvisation, and the reflection of creativity levels of students on their improvisation abilities should be re-examined. In addition, it can be suggested that this descriptive study conducted at the university level should be done with other instruments and different age groups. 


\section{REFERENCES}

Aslan, E. (2001). Torrance Yaratıcı Düşünce Testi'nin Türkçe versiyonu. M.Ü. Atatürk Eğitim Fakültesi Eğitim Bilimleri Dergisi, 14, 19-40. Retrieved from https://dergipark.org.tr/tr/pub/maruaebd/issue/368/2523.

Azzara, C. D. (1992). The Effect of Audiation-Based Improvisation Techniques On the Music Achievement of Elementary Instrumental Music Students [Unpublished doctoral dissertation]. University of Rochester.

Batıbay, D., Piji, D. (2006). Müzik Öğretmeni Adaylarının Müzik Derslerindeki Başarıları ile Müzikal Yaratıcılıkları Arasındaki Ilişki. M. Ü. Atatürk Ĕ̆itim Fakültesi Ĕ̆itim Bilimleri Dergisi, 23, 51-68.

Büyüköztürk, Ş., (2009). Sosyal Bilimler Için Veri Analizi El Kitabı. Ankara: Pegem Akademi.

Büyüköztürk, Ş., Kılıç Çakmak, E., Akgün, Ö. E., Karadeniz, Ş., Demirel, F. (2014). Bilimsel Araştırma Yöntemleri. Ankara: Pegem Akademi.

Creswel, J. W. (1999). Mixed-Method Research: Introduction and Application. (G. P. Phye, Ed.) Handbook of Educational Policy (pp. 455-472). Cambridge: Academic Press.

Çevik, B. D. (2011). Müzik Öğretmeni Adaylarının Eşlik Dersine Bakış Açıları ile Derste Zorlandıkları Konulara Ilişkin Çözüm Önerileri. Kastamonu Eğitim Dergisi, 19 (1), 345-360. Retrieved from https://dergipark.org.tr/tr/pub/kefdergi/issue/49053/625845.

Çevik, S. (2004). Yürürlükteki Müzik Öğretmenliği Lisans Programı Tasarısına Ilişkin Görüşler Öneriler. 19242004 Musiki Muallim Mektebinden Günümüze Müzik Öğretmeni Yetiştirme Sempozyumu. Retrieved from http://www.muzikegitimcileri.net/bilimsel/bildiri/S-Cevik_2.pdf.

Çokluk, Ö., Şekercioğlu, G., Büyüköztürk, Ş. (2012). Sosyal Bilimler Için Çok Değişkenli Istatistik SPSS ve Lisrel Uygulamaları. Ankara: Pegem Akademi.

Görsev, A. (2006). Abant İzzet Baysal Üniversitesi Müzik Eğitimi Anabilim Dalı Son Sını Öğrencilerinin "Piyano Eğitimi", "Müzik Teorisi ve İşitme Eğitimi" ve "Eşlik (Korepetisyon)" Dersleri Ile Okul Şarkılarına Doğaçlama Eşlik Becerileri Arasındaki Iliş̧iler [Unpublished master's thesis]. Abant İzzet Baysal University.

Güleç, G. (2017). Keman Çalmada Doğaçlama Çalışmalarının Öğrencilerin Müzikal Yaratıcılık Ve Keman Çalma Performansları Üzerindeki Etkileri (Buca Ĕ̆itim Fakültesi Örneği) [Unpublished doctoral dissertation]. Gazi University.

Kalkanoğlu, B. (2007). Okul Şarkılarının Müzik Öğretmenlerinin Bilgi Ve Beceri Düzeyine Göre Piyano ile Eşliklenmesine Yönelik Bir Model Önerisi [Unpublished master's thesis]. Gazi University.

Kalyoncu, N. (2005). Eğitim Fakültelerinde Uygulanan Müzik Öğretmenliği Lisans Programının Revizyon Gerekçeleriyle Tutarlılı̆̆ı. Gazi Eğitim Fakültesi Dergisi. 25 (3), 207-220. Retrieved from http://www.gefad.gazi.edu.tr/tr/pub/issue/6755/90834.

Kandemir, T. (2009). İlköğretim Sınıf Müzik Eğitiminde Orff Yaklaşımıyla Doğaçlama Çalışmalarının Müziksel Yaratıcık Sürecine Etkisi [Unpublished master's thesis]. Marmara University.

Karasar, N. (2006). Bilimsel Araştırma Yöntemi. Nobel Yayın Dağıtım.

Kaya, A., Bilen, S. (2016). Assessment of Creativity Based Learning Environment For Major Instrument Courses: A Case Study of Buca Faculty of Education, Department of Music Education. Journal of Human Sciences, 13 (2), 3102-3111. doi: http://dx.doi.org/10.14687/jhs.v13i2.3873.

Kaya, A., Bilen, S. (2017). Thinking Creatively with Sounds and Words: Sounds and Images IIA" Validity Study in the Turkish Language. Journal of Human Sciences, 14 (4), 3956-3967. doi: https://doi.org/10.14687/jhs.v14i4.5061. 
Khatena, J., Torrance, E.P. (1998). Thinking Creatively with Sound And Words Norms-Technical Manual. Illinois: Scholastic Testing Service.

Kornbrot, D. (2005). Point Biserial Correlation. Encyclopedia of Statistics in Behavioral Science: Volume 3 (Brian S. Everitt \& David C. Howell, Ed.). Chichester: John Wiley \& Sons.

Küpana, M. N. (2013). Müzikal Yaratıcılığı Geliştiren Yaklaşımlar. Eğitim ve Öğretim Araştırmaları Dergisi, 2 (2), 26-34. Retrieved from http://www.jret.org/FileUpload/ks281142/File/03._m._nevra_kupana.pdf.

Orhon, G. (2014). Yaratıcllı: Nörofizyolojik, Felsefi ve Ĕ̈itsel Temeller. Ankara: Pegem Akademi.

Otacıoğlu, S. G. (2006). Müzik Öğretmeni Yetiştiren Kurumlarda Müzik Eğitimi Alan Öğretmen Adaylarının, Müzikal Alg1 ve Özgüvenleri ile Okul ve Çalg1 Başarı Düzeyleri Arasındaki Ilişki. Ulusal Müzik Ĕ̆itimi Sempozyumu. Retrieved from http://www.muzikegitimcileri.net/bilimsel/bildiri/pamukkale/SOtacioglu.pdf.

Özben, Ş. ve Argun, Y. (2002). Sosyo Demografik Özelliklere Göre Üniversite Öğrencilerinin Yaratıclık Düzeylerinin Incelenmesi. Dokuz Eylül Üniversitesi Buca Eğitim Fakültesi Dergisi, 14, 8-17. Retrieved from https://acikerisim.deu.edu.tr/xmlui/bitstream/handle/20.500.12397/436/14-2.pdf?sequence=1\&isAllowe $\mathrm{d}=\mathrm{y}$.

Özer, B. (2014). Piyano Eğitiminde Çözümleme Destekli Çalışma Metodunun Işlevsel Piyano Çalma Becerilerine Etkisi [Unpublished doctoral dissertation]. Necmettin Erbakan University.

Padula, A. (2009). Encyclopedia of Giftedness, Creativity and Talent: Volume 2 (B. Kerr, Ed.). SAGE Reference Publication.

Rouquette, M-L. (1992). Yaratıcllk. (I. Gürbüz, Tr.). İstanbul: İletişim Yayınları. (1989).

San, İ. (1977). Sanatsal Yaratma ve Çocukta Yaratıcıllk. İstanbul: Türkiye İş Bankası Kültür Yayınları.

. (1985). Sanat ve eğitim: Yaratıcılık-Sanat Sorunları, Kuramları ve Eleştirisi- Eğitimle Ilişkiler. Ankara: Ankara Üniversitesi Basımevi.

. (1993). Yaratıcılık ve Ĕ̆itim. In (A. Ataman, Ed.). Sanatta Yaratıcılık, Oyun, Drama. Türk Eğitim Derneği Eğitim Dizisi, Vol. 17, 71-99. Ankara: Şafak.

(2004). Sanat ve Eğitim. Ankara: Ütopya.

Sungur, N. (1992). Yaratıcı Düşünce. Ankara: Özgür.

Tarman, S. (2006). Müzik Ĕ̆itiminin Temelleri. Ankara: Müzik Eğitimi.

Torrance Test of Creative Thinking (TTCT). (2016. April 20). In Scholastic Testing Service. Retrieved from https://www.ststesting.com/gift/.

Volz, M. D. (2005). Improvisation Begins with Exploration. Music Educator Journal. 92(1). 50-53. doi: https://doi.org/10.2307/3400227.

Wegerif, R. (2007). Dialogic Education and Technology. New York: Springer.

Wigram, T. (2005). Improvisation: Methods and Techniques for Music Therapy Clinicians, Educators and Students. London: Jessica Kingsley.

Wright, R. ve Kanellopoulos, P. (2010). Informal Music Learning, Improvisation and Teacher Education. British Journal of Music Education. (27), 71-87. doi: https://doi.org/10.1017/S0265051709990210.

Yavuzer, H. S. (1989). Yaratıcılık. İstanbul: Boğaziçi Üniversitesi. 
Yenilmez, K. ve Yolcu, B. (2007). Öğretmen Davranışlarının Yaratıcı Düşünme Becerilerinin Gelişimine Katkısı. Manas Üniversitesi Sosyal Bilimler Dergisi. (18), 95-105. Retrieved from https://dergipark.org.tr/tr/pub/manassosyal/issue/49947/640065

Yıldırım, A. ve Şimşek, H. (2016). Sosyal Bilimlerde Nitel Araştırma Yöntemleri. Ankara: Seçkin. 